\title{
Factors determining family planning in Catalonia. Sources of inequity
}

Carme Saurina ${ }^{1,2^{*}}$, Laura Vall-Ilosera ${ }^{1}$ and Marc Saez ${ }^{1,2}$ on behalf of the GESIC collaborative group

\begin{abstract}
Introduction: In recent decades, the foreign population in Spain has increased significantly, particularly for Catalonia, an autonomous region of Spain (2.90\% in 2000 and 15.95\% in 2010) and in particular Girona province (6.18\% in 2000 and $21.55 \%$ in 2010). Several studies have shown a lower use of family planning methods by immigrants. This same trend is observed in Spain. The objective of this paper is to determine the existence of differences and possible sources of inequity in the use of family planning methods among health service users in Catalonia (Spain) by sex, health status, place of birth and socioeconomic conditions.

Methods: Data were taken from an ad-hoc questionnaire which was compiled following a qualitative stage of individual interviews. Said questionnaire was administered to 1094 Catalan public health service users during 2007. A complete descriptive analysis was carried out for variables related to public health service users' sociodemographic characteristics and variables indicating knowledge and use of family planning methods, and bivariate relationships were analysed by means of chi-square contrasts. Considering the use (or non-use) of family planning methods as a dependent variable and a set of demographic, socioeconomic and health status variables as explanatory factors, the relationship was modelled using mixed models.
\end{abstract}

Results: The analysed sample is comprised of $54.3 \%$ women and $45.7 \%$ men, with $74.3 \%$ natives (or from the EU) and $25.7 \%$ economic immigrants. $54.8 \%$ use some method of family planning, the condom (46.7\%) and the pill (28.0\%) being the two most frequently used methods. Statistical modelling indicates that those factors which most influence the use of family planning methods are level of education (30.59\% and $39.29 \%$ more likelihood) and having children over 14 (35.35\% more likelihood). With regard to the origin of the user, we observe that patients from North Africa,sub. Saharan Africa and Asia are less likely to use family planning methods $(36.68 \%, 38.59 \%$ and $70.51 \%$, respectively).

Conclusions: The use of family planning methods is positively related to a higher level of education and having children over 14. Factors such as sex, age, income and self-perceived health do not appear to influence their use. Furthermore, being a native of this country, the European Union or Central/South America represents a greater likelihood of use than being African or Asian. Although no general differences in use were found between sexes, the difference found in the case of Asian women stands out, with a higher likelihood of use.

Keywords: Inequalities, Family planning, Immigration, Mixed models

\footnotetext{
*Correspondence: carme.saurina@udg.edu

'Research Group on Statistics, Econometrics and Health (GRECS), University of Girona, Campus de Montilivi, 17071 Girona, Spain

${ }^{2}$ CIBER of Epidemiology and Public Health, Campus de Montilivi, 17071

Girona, Spain
}

\section{Biomed Central}

(c) 2012 Saurina et al.; licensee BioMed Central Ltd. This is an Open Access article distributed under the terms of the Creative Commons Attribution License (http://creativecommons.org/licenses/by/2.0), which permits unrestricted use, distribution, and reproduction in any medium, provided the original work is properly cited. 


\section{Introduction}

In recent decades, the foreign population in Spain has increased from $1.60 \%$ of the total population in 1998 to $12.20 \%$ in 2011 [1]. Changes in the annual rates are even greater for Catalonia, an autonomous region of Spain, (2.90\% in 2000 and $15.95 \%$ in 2010 ) and in particular Girona province (6.18\% in 2000 and $21.55 \%$ in 2010) [2].

Inequity in access to and use of different contraceptive methods affects human rights [3]. Although for immigrants from low-income countries or countries with deficient health services migrating may provide a greater opportunity to access sexual and reproductive health services in the host country, it is often the different barriers to access (such as difficulty with the language, dealing with health professionals or lack of information) in addition to structural, social and cultural factors, that determine real opportunities to use said services.

Numerous studies have analysed the situation regarding the use of family planning methods in developing countries [4-13] and developed countries [14-18], and studies also exist on differences between native and immigrant populations of developed countries. However, talking about inequities in the use of family planning methods is more difficult than talking about health inequities in general [19-21], because, in addition to objective factors regarding knowledge of and access to said methods, there is also the influence of moral issues, such as the fear of transgressing certain taboos, cultural factors and even religious impediments. In developing countries, and particularly African countries, it is important to take into account that the attitudes towards and use of contraception may vary due to a multitude of factors, including the quality of the health service and its professionals, availability of and access to family planning methods [22], level of wealth [23], gender roles and the socioeconomic context of the country [20]. Discrepancies have also been found in developing countries with regard to interest in modern family planning methods and their real use. Some results suggest that more support is required to ensure greater prevalence of use, in terms of access to different methods and from an educational and cultural viewpoint [16], as well as greater involvement by health professionals [17].

Research into differences in the use of family planning methods between immigrant and native populations in different countries generally indicates less use by immigrants [24-26], even when they have resided in the host country for some time [21] . This same trend is observed in Spain, with less frequent use of the health service by the immigrant population when it comes to the general health service [27-29] and family planning clinics and the use of different methods of contraception [30,31], especially for certain groups of immigrants.
The main aim of this study is to detect sources of inequity by analysing factors influencing the use or non-use of family planning methods in a geographical context where there is a high level of relatively recent immigration and a public health system which offers universal cover. The consequences of less access to family planning services are not only a higher number of undesired pregnancies but also increased risk of infections and sexually transmitted diseases, and higher numbers of abortions $[14,15,25]$.

\section{Methods}

The data used in this study were taken from a questionnaire administered to a sample of Catalan health service users. The health care system in Catalonia has all the powers derived from the Spanish constitution. The

\section{Table 1 Descriptive demographic and socioeconomic} variables

\begin{tabular}{|c|c|c|}
\hline Characteristics & Number of cases $(n)^{*}$ & ${ }^{*}$ Percentage $(\%)^{* *}$ \\
\hline \multicolumn{3}{|l|}{ Sex } \\
\hline Male & 414 & 45.7 \\
\hline Female & 462 & 54.3 \\
\hline \multicolumn{3}{|l|}{ Place of birth } \\
\hline Native & 346 & 69.1 \\
\hline European Union & 53 & 5.2 \\
\hline Eastern Europe & 40 & 3.4 \\
\hline Central and South America & 163 & 7.2 \\
\hline North Africa & 136 & 6.8 \\
\hline Sub-Saharan Africa & 67 & 2.2 \\
\hline Asia & 71 & 5.9 \\
\hline \multicolumn{3}{|l|}{ Level of education } \\
\hline Primary school unfinished & 229 & 24.3 \\
\hline Secondary school finished & 424 & 50.5 \\
\hline Higher & 221 & 25.2 \\
\hline \multicolumn{3}{|l|}{ Having children under 14} \\
\hline No & 131 & 26.5 \\
\hline Yes & 301 & 73.5 \\
\hline Missing data & 444 & 55.9 \\
\hline \multicolumn{3}{|l|}{ Suffering chronic illness } \\
\hline No & 647 & 72.6 \\
\hline Yes & 224 & 27.4 \\
\hline \multicolumn{3}{|l|}{ Self-perceived health status } \\
\hline Poor & 22 & 2.1 \\
\hline Normal & 180 & 18.2 \\
\hline Good & 367 & 44.3 \\
\hline Very good & 235 & 28.3 \\
\hline Excellent & 67 & 7.1 \\
\hline
\end{tabular}

*Unweighted n's and ** weighted percentages (\%). 
Table 2 Distribution of users according to age group

\begin{tabular}{lc}
\hline Distribution by age in quartiles & Number of cases $(\mathbf{n})^{*}$ \\
\hline Aged 15-25 & 202 \\
Aged 26-31 & 204 \\
Aged 32-38 & 197 \\
Aged 39-49 & 207 \\
\hline *Unweighted $n^{\prime}$ (\%)
\end{tabular}

Spanish model decentralizes the responsibility for health to autonomous communities.

It is a validated ad-hoc questionnaire with copyright $\mathrm{n}$ 02/2010/2833 [32]. The questionnaire was compiled following a qualitative stage involving the conducting of 37 individual interviews to users, health professionals and cultural mediators aimed at drawing out sensitive information and determining opinions regarding the possible existence of access barriers to a public and universal health service such as the one in Spain. The questionnaire was administered to 1094 public health service users at health centres in Girona (ABS Salt and Santa Caterina Hospital), BaixEmpordà (Palamòs Hospital and Palafrugell ABS), Barcelona (Hospital del Mar, Raval Sur ABS, Vila Olímpica ABS and Besòs ABS) and Lleida (Arnau de Vilanova Hospital, RamblaFerran ABS and Eixample ABS) in 2007. Point transect sampling was used in order to ensure the representativeness of the sample [29] . Given the aim of the article, only users aged between 15 and 49 were selected, which meant working with a total of 876 complete questionnaires. Data were weighted in order to correctly reflect the distribution of the population of users according to origin.

Data analysis comprised a complete descriptive analysis of variables relating to the sociodemographic and health status characteristics of public health service users and variables indicating their knowledge and use of family planning methods (Tables 1, 2 and 3). Bivariate relationships were analysed by means of chi-square contrasts between the variable indicating use or non-use of family planning methods and the variable addressing the type of method used and users' sociodemographic variables and health characteristics (Tables 4 and 5). Finally, considering the use (or non-use) of family planning methods as a dependent variable and a set of demographic, socioeconomic and health status variables as explanatory factors, the relationship was modelled using mixed models.
The model studies factors that have a greater or lesser influence on the likelihood of using family planning methods. Thus, the model to be estimated is specified as follows [eq.(1)]:

$$
\ln \left(\frac{\operatorname{Pr}\left(Y_{i}=1\right)}{1-\left[\operatorname{Pr}\left(Y_{i}=1\right)\right]}\right)=\beta_{0 i}+\sum_{j=1}^{J} \beta_{j} X_{j i}
$$

where $\mathrm{Y}$ is the response variable, that is, use or non-use of family planning methods and $\operatorname{Pr}(\mathrm{Y}=1)$ refers to the likelihood of using family planning methods and is modelled by a logistic regression. $\mathrm{X}$ refers to the group of users' sociodemographic and health status variables. The special feature offered by this model is that it introduces the heterogeneity $\beta_{0 i}=\beta_{0}+\eta_{1}$ associated with the user through a normal random effect, where $\eta_{l} \rightarrow\left(0, \tau_{\eta}\right)$. This modification allows us to collect the individual effects that are not explained by the explanatory variables of the model (those that depend uniquely on the patient). Due to the multiple advantages it provides within the context of this study, the aforementioned models are estimated using the Bayesian approach [33-35]. All computations were carried out using the interface INLA, running directly in $\mathrm{R}$ (version $\mathrm{R}$ 2.11.0) [36].

Different effects were tested, both fixed and random, in order to determine the final specification of the model. Models were compared using the DIC (Deviance Information Criterion) and the conditional predictive ordinate (CPO) for each observation (in fact - mean (log (cpo)). CPO is a cross-validated predictive approach, i.e. predictive distributions conditioned on the observed data with a single data point deleted. Asymptotically the CPO statistic has a similar dimensional penalty to AIC. From this perspective, the $\mathrm{CPO}$ statistic may be similar to DIC. In both cases, the lower the DIC or the CPO, the better the model. The finally selected model is shown in Table 6.

\section{Results}

The main descriptive results shown in Tables 1, 2 and 3 indicate a weighted percentage of $54.3 \%$ of women and $45.7 \%$ of men. $74.3 \%$ are natives or from EU countries, and $25.7 \%$ economic immigrants (according to the UNDP country classification [37]). $24.3 \%$ state having a low level of education, while $25.2 \%$ have studied in

Table 3 Type of planning methods used among those who use them

\begin{tabular}{lccccc}
\hline Use of family planning methods & Permanent methods & IUD/vaginal ring & Pill & Condom & $\begin{array}{l}\text { Other: Traditional, injections, patches, } \\
\text { implants, morning after pill,... }\end{array}$ \\
\hline Number of cases $(n)^{*}$ & 43 & 45 & 136 & 203 & 29 \\
Percentage $(\%)^{* *}$ & 10.2 & 9.4 & 28.9 & 46.7 & 4.9 \\
\hline
\end{tabular}

Missing data ( $n=420,45.2 \%)$. *Unweighted $n$ 's and ${ }^{* *}$ weighted percentages (\%). 
Table 4 Relationship between the use of family planning methods and user characteristics

\begin{tabular}{lccl}
\hline Use of family planning methods & Chi-square (V Cramer) & p-value & Interpretation (use less) \\
\hline Age in quartiles & $10.959(0.117)$ & 0.012 & Aged 39-49 \\
Place of birth & $37.361(0.216)$ & 0.000 & $\begin{array}{l}\text { European Union and Central-South America } \\
\text { use more Africans and Asians use less }\end{array}$ \\
Level of education & $8.630(0.104)$ & 0.013 & Primary education lessHigher education more \\
Basic origin & $4.915(0.078)$ & 0.000 & Immigrants \\
Having children under 14 & $10.971(0.176)$ & 0.001 & Not having children
\end{tabular}

No differences with regard to sex, type of family planning methods used, chronic illness, self-perceived health and income.

higher education. With regard to health status, 27.4\% state they have a chronic illness while $20.3 \%$ perceive their health to be normal or poor. $54.8 \%$ of users in the sample state they regularly use some method of family planning, with the pill $(28.9 \%)$ and the condom $(46.7 \%)$ the most common.

The bivariate relationships shown in Table 4 indicate significant relationships at $95 \%$ of confidence regarding the use of family planning methods in the variables age, place of birth (see Figure 1), level of education, basic origin and having children under 14 . The relationships indicate that those who use family planning methods less are older people (39 to 49 year-olds), Africans and Asians, people with primary school education (see Figure 2) and those without children. No statistically significant relationships are found with regard to sex, type of family planning methods used, income or perceptions of health.

Table 5 shows statistically significant relationships at 95\% confidence with regard to type of family planning methods. No significant differences are found in the type of planning method used with regard to income or basic origin (natives and European Union versus economic immigrants) although differences do stand out when

Table 5 Relationship between the type of family planning methods used and user characteristics

\begin{tabular}{|c|c|c|c|}
\hline Type of family planning methods used & Chisquare (V Cramer) & p-value & Interpretation \\
\hline \multirow[t]{2}{*}{ Sex } & $43.377(0.313)$ & 0.000 & Men: more condoms \\
\hline & & & Women: more pill and other \\
\hline \multirow[t]{3}{*}{ Age in quartiles } & $84.196(0.252)$ & 0.000 & Aged 15-38: less permanent methods \\
\hline & & & Aged 39-49: more permanent methods and IUD \\
\hline & & & Aged >45: more permanent methods \\
\hline \multirow[t]{3}{*}{ Level of education } & $19.248(0.147)$ & 0.014 & Primary: more permanent methods and other \\
\hline & & & Secondary: more condoms less others \\
\hline & & & Higher: less permanent methods \\
\hline \multirow[t]{8}{*}{ Place of birth } & $37.285(0.145)$ & 0.041 & Natives: more permanent methods, condoms \\
\hline & & & European U: more condoms \\
\hline & & & less IUD and permanent methods \\
\hline & & & Eastern Europe: less IUD and other \\
\hline & & & Central-South America: more IUD-ring and other \\
\hline & & & North Africa: more pill \\
\hline & & & Sub-Saharan Africa more other \\
\hline & & & Asia: more other \\
\hline \multirow[t]{2}{*}{ Children under 14} & $9.467(0.226)$ & 0.050 & Yes: more IUD/vaginal ring \\
\hline & & & less permanent methods \\
\hline \multirow[t]{2}{*}{ Self-perceived health } & $29.451(0.129)$ & 0.021 & Better: more IUD \\
\hline & & & Worse: more permanent methods \\
\hline \multirow[t]{2}{*}{ Chronic illness } & $9.434(0.146)$ & 0.051 & Yes: more permanent methods \\
\hline & & & less condoms \\
\hline
\end{tabular}


Table 6 Model results

\begin{tabular}{|c|c|}
\hline & RR $(95 \% \mathrm{Cl})^{1}$ \\
\hline \multicolumn{2}{|l|}{ AGE } \\
\hline Aqeq1 (15-25) & 1 \\
\hline Ageq2 (26-31) & $0.9779(0,7521-1.2485)$ \\
\hline Ageq3 (32-38) & $0.8544(0.6477-1.1043)$ \\
\hline Ageq4 (39-49) & $0.7977(0.5899-1.0502)$ \\
\hline \multicolumn{2}{|l|}{ SEX } \\
\hline male & 1 \\
\hline female & $0.8954(0.6711-1.1724)$ \\
\hline \multicolumn{2}{|l|}{ ORIGIN } \\
\hline Native & 1 \\
\hline European Union & $1.3619(0.7237-2.226)$ \\
\hline Eastern Europe & $0.8820(0.3334-1.7408)$ \\
\hline Central and South America & $1.1707(0.7921-1.6478)$ \\
\hline North Africa & $0.6332(0.3947-0.9369)$ \\
\hline Sub-Saharan Africa & $0.6141(0.3342-0.9805)$ \\
\hline Asia & $0.2949(0.1202-0.5580)$ \\
\hline \multicolumn{2}{|l|}{ EDUCATION } \\
\hline Primary & 1 \\
\hline Secondary & $1.3059(1.0028-1.6807)$ \\
\hline University & $1.3929(1.0302-1.8460)$ \\
\hline \multicolumn{2}{|l|}{ Interaction sex*origin } \\
\hline Male and native? & 1 \\
\hline Female and European Union & $0.9433392(0.4328-1.8276)$ \\
\hline Female and Eastern Europe & $0.9045(0.2802-2.2907)$ \\
\hline Female and Central and South America & $0.9740(0.5902-1.5213)$ \\
\hline Female and North Africa & $1.1367(0.5794-2.0090)$ \\
\hline Female and sub-Saharan Africa & $1.4626(0.4911-3.2330)$ \\
\hline Female and Asia & $3.3542(1.1195-8.0612)$ \\
\hline \multicolumn{2}{|l|}{ Children over 14} \\
\hline NO & 1 \\
\hline YES & $1.3535(1.0917-1.6564)$ \\
\hline \multicolumn{2}{|l|}{ Self-perceived health } \\
\hline Poor & 1 \\
\hline Normal & $0.8468(0.6303-1.1466)$ \\
\hline Good & $0.8808(0.6835-1.1610)$ \\
\hline Very good & $0.8951(0.6816)$ \\
\hline Excellent & $1.0960(0.7763-1.5374)$ \\
\hline \multicolumn{2}{|l|}{ Number of chronic illnesses } \\
\hline None & 1 \\
\hline One & $1.1264(0.8722-1.4206)$ \\
\hline More than one & $1.0289(0.6353-1.5214)$ \\
\hline Individual heterogeneity $(\mathrm{sd})^{2}$ & 0.010427554 \\
\hline $\mathrm{DIC}$ & 1491.48 \\
\hline
\end{tabular}

Table 6 Model results (Continued)

\begin{tabular}{ll}
\hline Effective number of parameters & 26.68 \\
$-\log ($ mean(cpo)) & 0.8586142 \\
\hline${ }^{1}$ Mean (95\% Credible Interval) 2 Mean (Standard Deviation).
\end{tabular}

working with different origins of economic immigrants (see Figure 3). Thus, for example, it is worth highlighting that users from sub-Saharan Africa and Asian countries use traditional methods more frequently.

Finally, Table 6 shows the results of the statistical modelling. It is observed that individuals from North Africa, sub-Saharan Africa and Asia are less likely (36.68\%, $38.59 \%$ and $70.51 \%$, respectively) to use family planning methods than natives. That said, when we analyse this relationship taking into account users' sex and origin, we observe that women from these geographical regions are more likely to use family planning methods than native men, although only Asian women show a statistically significant relationship in this respect (235\% more likelihood than native men). Furthermore, users with secondary and university education have a greater likelihood of using family planning methods $(30.59 \%$ and $39.29 \%$, respectively) than individuals with primary education. People with children over 14 have a $35.35 \%$ more likelihood of using family planning methods than those without children. No significant relationships are detected with regard to perceived health status or chronic illness.

\section{Discussion}

The article highlights the difference in use of family planning and contraception among different groups in a geographical region with a high rate of recent immigration where there is universal health cover and analyses the possible existence of sources of inequity in this different use of family planning methods.

Despite the fact that, as we have said, it is difficult to conclude whether the differences detected may be considered solely inequalities, in the sense that they reflect different patterns of behaviour and different preferences in the choice of family model due to sociological and cultural type reasons, we believe that the results do point, as Gillespie et al. [21] suggest, to the inequalities detected in this case being considered sources of inequity. Greater fertility rates among African and Asian populations, which according to the UNDP [37] comprise a proportion of economic immigrants to this country, along with less use of contraceptive methods (Table 7) suggest that the inequalities detected may be considered inequities in contraception in these populations when compared with the native population and populations from other geographical locations.

The main limitations in the interpretation of these results relate to the use of a sample of public health 


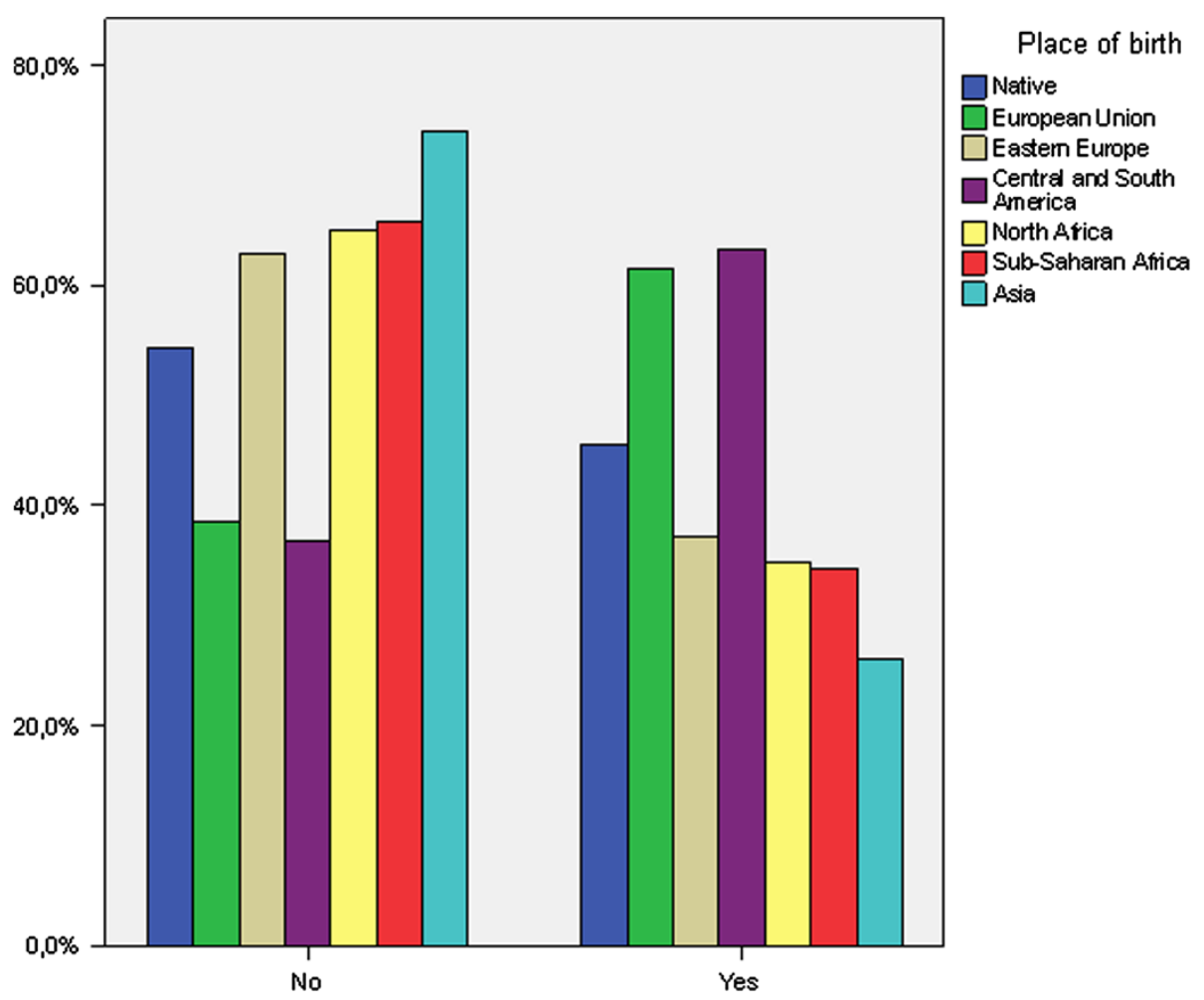

Figure 1 Relationship between the use of family planning methods and place of birth.

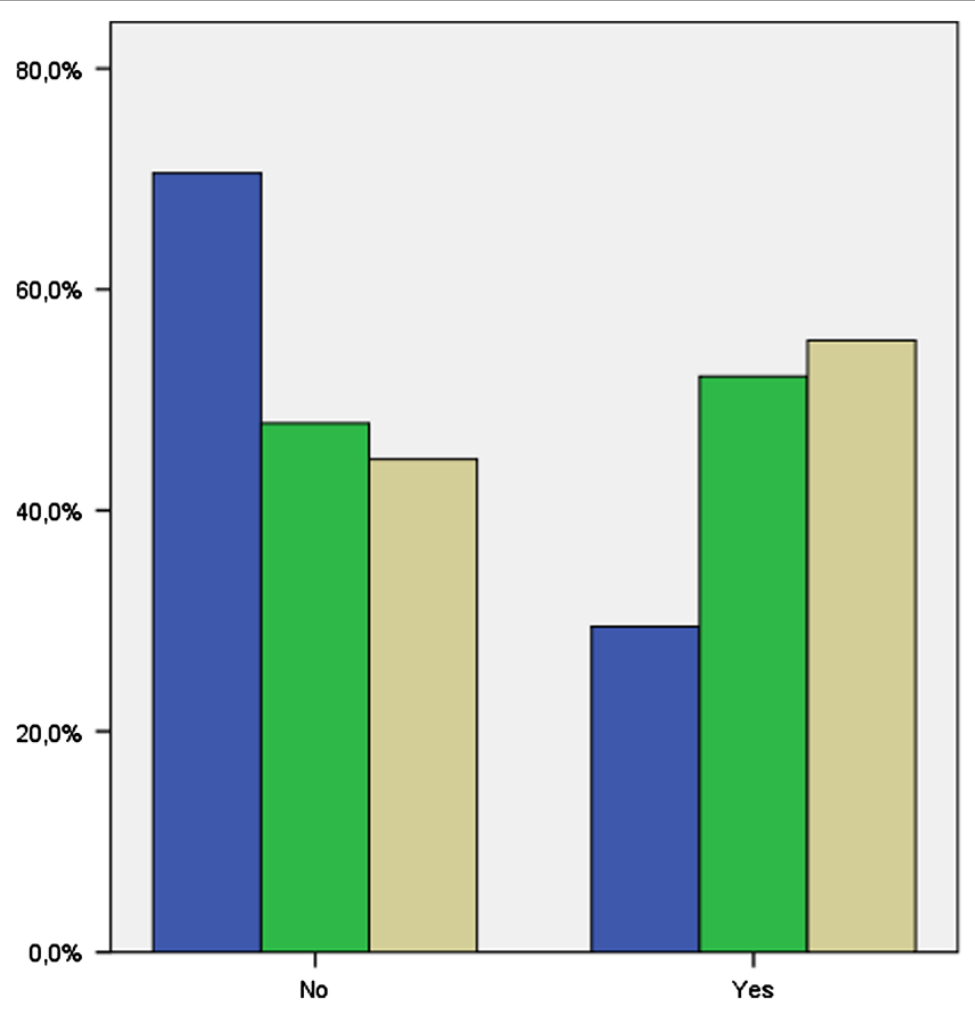

Level of education

$\square$ Primary

Secondary

$\square$ Higher 


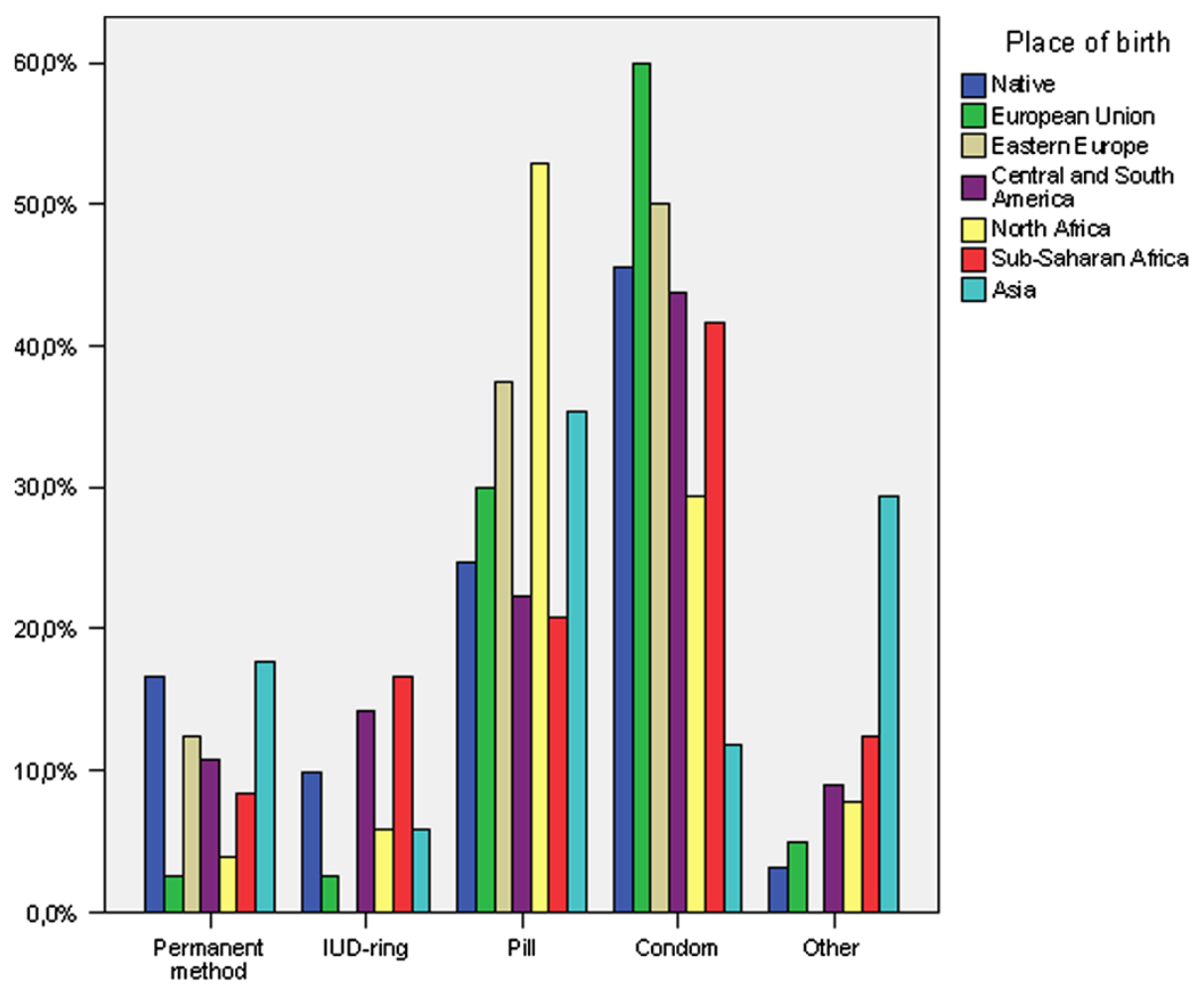

Figure 3 Relationship between the use of family planning methods used and place of birth.

services users during a specific period of time (year 2007) and not a random sample of the population and also are worth mentioning that the questionnaire used not provided detailed information regarding the individual incomes of these users. Despite said limitations, these results provide relevant information for planning improvements in the use of health services in this country.

\section{Conclusion}

As follows from this analysis, greater or lesser use of family planning methods is related only to socioeconomic factors and not health status (real or perceived). Level of education, having children over 14 and geographical origin are elements that determine use. Even

Table 7 Fertility rates by origin

\begin{tabular}{llllll}
\hline Users with children & $\%$ & mean & sd & min & max \\
\hline Natives & 41.3 & 1.73 & 0.751 & 1 & 4 \\
European Union & 17.5 & 1.23 & 0.451 & 1 & 2 \\
Eastern Europe & 45.3 & 1.78 & 0.893 & 1 & 4 \\
Central and South America & 57,7 & 1.89 & 0.965 & 1 & 5 \\
North Africa & 61.3 & 2.11 & 1.064 & 1 & 6 \\
Sub-Saharan Africa & 67.2 & 2.42 & 1.579 & 1 & 8 \\
Asia & 56.3 & 2.13 & 1.390 & 1 & 5 \\
\hline
\end{tabular}

in Spain, a country with universal health service access, we have found sources of inequity. These results agree with the arguments proposed by Creanga [22], Davis [20], Igbal [19] and Gillespie [21], in the sense that although the use of family planning methods is first and foremost influenced by knowledge of and access to the same, gender roles, moral and/or cultural type reasons and individuals' socioeconomic context also play an important role in this decision. This inequity is difficult to address from a solely medical point of view, as barriers to accessing family planning methods (difficulty with the language, dealing with health professionals, lack of information, etc.) refer to elements that must also be dealt with from a social viewpoint. Action in this respect would lead to a reduction in the number of undesired pregnancies and abortions, as well as fewer risks of infections and sexually transmitted diseases.

\footnotetext{
Abbreviations

ABS: AreaBásica de Salud or Local Health Region; INLA: Integrated Nested Laplace Approximations; DIC: Deviance Information Criterion;

CPO: conditional Predictive Ordinate; UNDP: United Nations Development Programme.

\section{Competing interests}

The authors declare that they have no competing interests.

Authors' contributions

CS designed the fieldwork which provided the data and worked on data modelling and drafting the article, MS did the statistical modelling and
} 
worked on drafting and revising the article, LV participated in the fieldwork which provided the data, data cleansing and the descriptive analysis of the same, and also worked on drafting and revising the article. All the authors read and approved the final manuscript.

\section{GESIC collaborative group}

Mercè Almirall ${ }^{1,2}$, Andrea Burón ${ }^{3}$, Xavier Cabré ${ }^{1,2}$, Dolors Corominas ${ }^{4}$, Pere Plaja $^{5}$, Dolors Muñoz ${ }^{6}$, Marc Saez ${ }^{7,8}$, Carme Saurina ${ }^{7,8}$, Catalina Serna ${ }^{9}$, Laura Serra ${ }^{7,8}$, Jorge Soler-González ${ }^{9}$, Esther Tobías ${ }^{10}$, Laura Vall-Ilosera ${ }^{8}$

${ }^{1}$ Biomedical Research Institut, Lleida (IRBLLEIDA), Spain

${ }^{2}$ University Hospital Universitari Arnau de Vilanova, Spain

${ }^{3}$ Hospital Mar-Parc de Salut MAR, Spain

${ }^{4}$ Institut d'AssistènciaSanitària de Girona (IAS), Spain

${ }^{5}$ Figueras Hospital, Spain

${ }^{6}$ University of Girona, Spain

${ }^{7}$ CIBER of Epidemiology and Public Health Spain

${ }^{8}$ Research Group on Statistics, Econometrics and Health (GRECS), University of Girona, Spain

${ }^{9}$ Regional Primary Care Management Office, Catalan Institute of Health,

University of Lleida Spain

${ }^{10}$ University Foundation of Bages (FUB), Spain

\section{Acknowledgments}

This work was partially supported by the FIS (Health Research Fund), Spanish Ministry of Science and Innovation, project FIS-07/0156.

Received: 6 April 2012 Accepted: 24 June 2012

Published: 20 July 2012

\section{References}

1. INE. Instituto Nacional de Estadística: NationalStatistics/nstitute, Spanish Statistical Office. www.ine.es.

2. Idescat: Instituto de Estadística de Cataluña. www.idescat.cat/es.

3. Jain AK: Fertility reduction and the quality of Family Planning Services. Stud Fam Plan 1989, 1:1-16.

4. White JS, Speizer IS: Can family planning outreach bridge the urban-rural divide in Zambia? BMC Heal Serv Res 2007, 7:143. doi:10.1186/1472-6963-7143. http://www.biomedcentral.com/1472-6963/7/143. 2007 White and Speizer; licensee BioMed Central Ltd.

5. Aliyu AA, Shehu AU, Sambo MN, Sabitu K: Contraceptive knowledge, attitudes and practice among maried women in Samaru community, Zaria, Nigeria. East Afr J Public health 2010 Dec, 7(4):342-344.

6. Omole-Ohons A, Ashimi A, Attah R: A Review of Family Planning Methods Used in Kano, Nigeria. Nigerian Journal of Clinical Medicine 2010, 3:1.

7. Bellows B, Warren C, Vonthanak S, Chhorvann C, Sokhom H, Men C, Bajracharya A, Rob $U$, Rathavy T: Evaluation of the impact of the voucher and accreditation approach on improving reproductive behaviors and status in Cambodia. BMC Publ Health 2011 Aug 24, 11:667.

8. Warren C, Abuya T, Obare F, Sunday J, Njue R, Askew I, Bellows B: Evaluation of the impact of the voucher and accreditation approach on improving reproductive health behaviors and status in Kenya. BMC Publ Health 2011 Mar 23, 11:177

9. Paul VK, Sachdev HS, Mavalankar D, Ramachandran P, Sankar MJ, Bhandari N, Sreenivas V, Sundararaman T, Govil D, Osrin D, Kirkwood B: Reproductive health, and child health and nutrition in India: meeting the challenge. Lancet 2011 Jan 22, 377(9762):332-349. Epub 2011 Jan 10.

10. Goicolea I, San Sebastián M, Wulff M: Women's reproductive rights in the Amazon basin of Ecuador: challenges for transforming policy into practice. Health Hum Rights 2008, 10(2):91-103.

11. Kaufman CE: Contraceptive use in South Africa under apartheid. Demography 1998 Nov, 35(4):421-434.

12. Gish O: Health and family planning services in Bangladesh: a study in inequality. Int J Health Serv 1981, 11(2):263-281.

13. Varga CA: How gender roles influence sexual and reproductive health among South African adolescents. Stud Fam Plann 2003 Sep, 34(3):160-172

14. Rasch V, Gammeltoft T, Knudsen LB, Tobiassen C, Ginzel A, Kempf L: Induced abortion in Denmark: effect of socioeconòmic situation and country of birth. Eur J Public Health 2008, 18:144-149.

15. Van Enk WJ, Gorissen WH, van nk A: Teenage pregnacy and ethnicity in The Netherlands: frequency and obstètric outcome. Eur J Contracept Reprod Health Care 2000, 5:77-84.
16. Mikolajczyk RT, Stanford JB, Rauchfuss M: Factors influencing the choice to use modern natural family planning. Contraception 2003 Apr, 67(4):253-258

17. Păfvăleanu M, Pricop Z, Azoicăi D, Boiculese LV, Cozma A, Pintilie M, Grigoraş RC, Nechita E, Herescu D: Questionnaire regarding the self perception of health status and attitude to family planning of the Roma population in laşi county. Rev Med Chir Soc Med Nat lasi 2007 Jan-Mar, 111(1):265-269.

18. Becker D, Koenig MA, Mi Kim Y, Cardona K, Sonenstein FL: The Quality of Family Planning Services in the United States: Findings from a Literature Review. Perspect Sex Reprod Heal 2007, 39:206-215.

19. Iqbal H, Shah, Chandra-Mouli V: Inequity and unwanted fertility in developing countries. Bull World Health Organ 2007 February, 85(2):86. World Health Organization (WHO) 2007.

20. Davis J, Lopez-Carr D: The effect of migrant remittances on populationenvironment dynamics in migrant origen areas: international migration, fertility, and consumption in highland Guatemala. Popul Environ 2010, $32: 216-237$

21. Gillespie D, Ahmed S, Tsui A, Radloff S: Unwanted fertility among the poor: an inequity? Bull World Health Organ 2007, 85(2):100-107.

22. Creanga AA, Gillespie D, Karklins S, Tsui AO: Low use of contraception among poor women in Africa: an equity issue. Bull World Health Organ 2011 Apr 1, 89(4):258-66. Epub 2011 Feb 1.

23. Rahman M, Haque SE, Mostofa MG, Tarivonda L, Shuaib M: Wealth inequality and utilization of reproductive health services in the Republic of Vanuatu: Insights from the Multiple Indicator Cluster Survey, 2007. Int J Equity Health. 2011 Dec 2, 10(1):58

24. Lamur HE: Characteristics of Caribbean-born women having abortions in an Amsterdam clínic. Genus 1993, 49:135-45.

25. Helstrom L, Zatterstrom C, Odlind V: Abortion rate and contraceptive practices in inmigrant and Swedish adolescents. J Pediatr Adolesc Gynecol 2006, 19.209-13.

26. Garces-Palacio IC, Altarac M, Scarinci IC: Contraceptive knowledge and use among low-income Hispanic inmigrant women an non-Hispanic women. Contraception 2008, 77:270-5

27. Vall-Ilosera L, Saurina C, Saez M: Inmigración y salud: necesidades y utilización de los servicios de atención primaria por parte de la población inmigrante en la región sanitaria Girona. Revista Española de Salud Pública. 2009, 83(2):291-307.

28. Saurina C, Vall-Ilosera L, Saez M: A Qualitative analysis of immigrant population health practices in the Girona Health Region. BMC Publ Health 2010, 10(1):379.

29. Saurina C, Vall-Ilosera L, Saez M: Factors determining access to and use of primary health care services in the Girona Health Region (Spain). Eur J HealthEcon 2012, 13(4):419-427.

30. Zurriaga O, Martinez Beneito M, Peñalver J, Bosch S, García M, Amador, et al: Análisis de las características diferenciales de las inmigraciones atendidas en centros de planificación familiar. Gac Sanit 2003, 17:115.

31. Baraza Cano MP, Lafuente Robres N, Granados Alba A: Identificación de diagnósticos enfermeros en población inmigrante en el distrito Poniente de Almería. Enfermería Comunitaria 2005, 1:18-23.

32. Encuesta de barreras de acceso, estado de salud y utilización de los servicios sanitarios en Catalunya (Soler J, Corominas D, Plaja P, Muñoz-Soler MD, Vall.llosera L, Burón A, Almirall mm, romero ar, saez m, Serna MC, Cabré FJ, Tobias E, Saurina C): Registro de la Propiedad Intelectual (obra literaria). N 02/2010/2833.

33. Gelfand AE, Dey DK, Chang H: Model determination using predictive distributions with implementation via sampling-based methods (with discussion). In Bayesian Statistics 4. Edited by Bernardo JM, Berger JO, Dawid AP, Smith AFM. Oxford: Oxford University Press; 1992.

34. Geisser S: Predictive Inference: An Introduction. London: Chapman and Hall; 1993.

35. Pettit LI: The conditional predictive ordinate for the normal distribution. J R Stat Soc Series B 1990, 52(1):175-184.

36. R-INLA project:; 2010. URL: http://www.r-inla.org/home.

37. PNUD (Programa de las Naciones Unidas para el Desarrollo). http://www. undp.org.

doi:10.1186/1475-9276-11-35

Cite this article as: Saurina et al:: Factors determining family planning in Catalonia. Sources of inequity. International Journal for Equity in Health 2012 11:35 